\title{
Energy and emergy analysis of mixed crop-livestock farming
}

\author{
Anna Kuczuk ${ }^{1, *}$, Janusz Pospolita ${ }^{1}$, and Stefan Wacław $^{2}$ \\ ${ }^{1}$ Opole University of Technology, ul. Prószkowska 76, 45-758, Opole, Poland \\ ${ }^{2}$ Opole Agricultural Advisory Centre, ul. Główna 1, 49-330, Łosiów, Poland
}

\begin{abstract}
This paper contains substance and energy balances of mixed crop-livestock farming. The analysis involves the period between 2012 and 2015. The structure of the presentation in the paper includes: crops and their structure, details of the use of plants with a beneficial effect on soil and stocking density per 1 ha of agricultural land. Cumulative energy intensity of agricultural animal and plant production was determined, which is coupled the discussion of the energy input in the production of a grain unit obtained from plant and animal production. This data was compared with the data from the literature containing examples derived from intensive and organic production systems. The environmental impact of a farm was performed on the basis of emergy analysis. Emergy fluxes were determined on the basis of renewable and non-renewable sources. As a consequence, several performance indicators were established: Emergy Yield Ratio $E Y R$, Environmental Loading Ratio $E L R$ and ratio of emergy from renewable sources $P_{R}$. Their values were compared with the parameters characterizing other production patterns followed in agricultural production. As a consequence, conclusions were derived, in particular the ones concerning environmental sustainability of production systems in the analyzed farm.
\end{abstract}

\section{Introduction}

Farming, along with other types of production, is associated with the need of application of a variety of means of production. In addition, farming is associated with the need of considerable energy input in it. This input takes the form of both the means of production (machines, equipment, fuel, fertilizers, and protection agents) as well as the ones that are extracted from the natural environment. In the case of these, we talk about energy derived from renewable sources (sun, wind, water and soil). Due to the fact that the discussion of energy aspects is often accompanied by the analysis of cost indices of production, whereas the use of the energy derived from free sources is often disregarded in the overall balance. This results in the fact that the calculations performed in such a manner do not account for the energy and cost associated with the decrease of the content of soil organic matter. In addition, such account does not involve the assessment of the sustainability of a given type of production.

The sun forms the fundamental source of energy for agricultural production. The mean energy flux absorbed by the earth is equal to $3.6 \mathrm{E}+4$ $\mathrm{GJ} \cdot \mathrm{ha}^{-1} \cdot$ year $^{-1}$ for the conditions in Poland [1]. The major portion of this flux participates in the heat exchange occurring between the soil, atmosphere and the background processes, whereas only a small fraction is used in the photosynthesis.

The process of agricultural production involves an input of a certain amount of energy of anthropogenic origin. For example, its cumulative values in the production of wheat is equal to 23.93 $\mathrm{GJ} \cdot \mathrm{ha}^{-1}$ in the conventional farms and $11.25 \mathrm{GJ} \cdot \mathrm{ha}^{-1}$ in the organic ones [2]. A portion of this energy is directly delivered to the ground in the form of seeds, natural and mineral fertilizers as well as plant protection agents. Such an assessment of the cumulative energy intensity of production accounts solely for the use of anthropogenic components. The emergy calculation proposed by Odum [3] provides grounds for a more extensive analysis, which involves the use of renewable energy sources. This analysis involves the reference of all energy fluxes to solar energy, which forms a primary source of all resources and their products.

This paper undertakes both the energy as well as emergy analysis of mixed crop-livestock farming. The farm that was taken for the analysis forms a representative one for the conditions in the Opole province. The application of the emergy analysis in the calculations provides an assessment with regard

Corresponding author: a.kuczuk@po.opole.pl 
to the sustainability of the production and use of natural resources on the farm.

\section{Materials and methods}

The results and analysis presented in this paper are based on data obtained from a farm located in the Opole province. The analysis of the data partly applied the data presented in detail in [4], after they were corrected and updated with details with regard to a further year. The selection of the farm was justified by the possibility of gaining comprehensive data for the period of four years (2012-2015), which provided grounds for a series of calculations with regard to the plant and animal production in it. The analysis was conducted with the purpose of determining the cumulative energy intensity and the use of the environmental resources. Such assessment can be applied from the practical perspective as it could serve in the decision making process regarding the directions applied in the production. The calculations of the cumulative energy intensity of crop production applies equation (1) [5-7].

$$
E_{c}=E_{m}+E_{f}+E_{m a t}+E_{l}[\mathrm{GJ}]
$$

where:

$E_{c}$-cumulative energy intensity of crop production $[\mathrm{GJ}]$,

$E_{m}-$ cumulative energy intensity in tractors, machinery, means of transport [GJ],

$E_{f}$ - cumulative energy intensity of the fuel [GJ],

$\mathrm{E}_{\text {mat }}$ - cumulative energy intensity of materials (fertilizers, sowing materials, protection agents) [GJ],

$E_{l}-$ cumulative energy intensity of human labor [GJ].

The following energy fluxes were applied for the calculation of the energy intensity of animal production (2):

$$
E_{a}=E_{m}+E_{f}+E_{m a t}+E_{l}+E_{\text {en }}[\mathrm{GJ}]
$$

where:

$E_{a}$ - cumulative energy intensity of animal production [GJ],

$E_{m}$ - cumulative energy intensity in tractors, machinery, means of transport [GJ],

$E_{f}-$ cumulative energy intensity of the fuel [GJ],

$E_{\text {mat }}$ - cumulative energy intensity of materials (fodder) [GJ],

$E_{l}$ - cumulative energy intensity of human labor [GJ],

$E_{\text {en }}$ - cumulative energy intensity of electricity [GJ].

The value of the two types of production was expressed in grain units (GU), and their cumulative energy intensity in $\mathrm{GJ} \cdot \mathrm{GU}^{-1}$. In addition, the cumulative energy intensity index was calculated and expressed in GU.GJ $J^{-1}$.

The emergy analysis forms a more objective measure. It is also used to determine the degree of loading and utilization imposed on the natural environment during the process of production $[3,8]$. The application of emergy analysis involves the conversion of each production process in relation to the use of solar energy, and emergy is defined by the product of exergy $E x$ of a given substance and its solar transformity $\tau(3)[3,9,10]$ :

$$
E m=E x \cdot \tau[\mathrm{seJ}]
$$

The unit of emergy is seJ, in turn exergy is defined as the minimum input of work required to derive a given substance in a specific time on the basis of common components available in the surrounding environment [11]. For the case of more complex products, e.g. machines, the study applies the notion of thermo-ecological cost, which is associated with the impact resulting from all stages of the manufacturing process. It expressed the cumulative use of exergy of non-renewable components of the environment [12]. The calculations of the emergy of the agricultural production applied the specific values of production and the renewable sources are presented in Table 1.

Table 1. Emergy of means of production and renewable sources.

\begin{tabular}{|l|c|c|c|}
\hline \multicolumn{1}{|c|}{$\begin{array}{c}\text { Type of } \\
\text { emergy }\end{array}$} & Value & Unit & Source \\
\hline $\begin{array}{l}\text { Solar } \\
\text { radiation }\end{array}$ & $0.989 \mathrm{E}+11$ & $\begin{array}{c}\mathrm{seJ} \cdot \mathrm{ha}^{-} \\
{ }^{1} \cdot \mathrm{day}^{-1}\end{array}$ & {$[13]$} \\
\hline $\begin{array}{l}\text { Evaporated } \\
\text { water }\end{array}$ & $1.28 \mathrm{E}+8$ & $\mathrm{seJ} \cdot \mathrm{kg}^{-1}$ & {$[3,9,10]$} \\
\hline Wind & $2.79 \mathrm{E}+10$ & $\begin{array}{c}\mathrm{seJ} \cdot \mathrm{ha}^{-} \\
1 \\
\mathrm{day}^{-1}\end{array}$ & $\begin{array}{c}{[3,10,} \\
14]\end{array}$ \\
\hline $\begin{array}{l}\text { Sowing } \\
\text { material }\end{array}$ & $6.50 \mathrm{E}+12$ & $\mathrm{seJ} \cdot \mathrm{kg}^{-1}$ & $\begin{array}{c}\text { own } \\
\text { calcul. }\end{array}$ \\
\hline $\begin{array}{l}\text { Nitrogen } \\
\text { fertilizers }\end{array}$ & $4.04 \mathrm{E}+13$ & $\mathrm{seJ} \cdot \mathrm{kg}^{-1}$ & {$[9]$} \\
\hline $\begin{array}{l}\text { Phosphorus } \\
\text { fertilizers }\end{array}$ & $3.69 \mathrm{E}+13$ & $\mathrm{seJ} \cdot \mathrm{kg}^{-1}$ & {$[9]$} \\
\hline $\begin{array}{l}\text { Potassium } \\
\text { fertilizers }\end{array}$ & $0.187 \mathrm{E}+13$ & $\mathrm{seJ} \cdot \mathrm{kg}^{-1}$ & {$[9]$} \\
\hline $\begin{array}{l}\text { CaO } \\
\text { fertilizers }\end{array}$ & $1.68 \mathrm{E}+12$ & $\mathrm{seJ} \cdot \mathrm{kg}^{-1}$ & {$[9]$} \\
\hline $\begin{array}{l}\text { Plant } \\
\text { protection } \\
\text { agents }\end{array}$ & $1.48 \mathrm{E}+13$ & $\mathrm{seJ} \cdot \mathrm{kg}^{-1}$ & {$[9]$} \\
\hline Human labor & $4.26 \mathrm{E}+13$ & $\mathrm{seJ} \cdot \mathrm{h}^{-1}$ & {$[9]$} \\
\hline Fuel & $5.13 \mathrm{E}+12$ & $\mathrm{seJ} \cdot \mathrm{kg}^{-1}$ & {$[9,15]$} \\
\hline $\begin{array}{l}\text { Machines and } \\
\text { equipment }\end{array}$ & $7.29 \mathrm{E}+14$ & $\mathrm{seJ} \cdot \mathrm{h}^{-1}$ & {$[3,12]$} \\
\hline $\begin{array}{l}\text { Organic } \\
\text { matter }- \text { decay }\end{array}$ & $10.02 \mathrm{E}+14$ & $\mathrm{seJ} \cdot \mathrm{ha}^{-1}$ & {$[9,10,16]$} \\
\hline Electricity & $1.6 \mathrm{E}+5$ & $\mathrm{seJ} \cdot \mathrm{J}^{-1}$ & {$[9]$} \\
\hline
\end{tabular}




\section{Results and discussion}

\subsection{Overview of data on analyzed farm}

The farm subjected to the analysis supports both animal and crop production. The average surface of the agricultural area (AL) of the farm was equal to 29.54 ha throughout 2012-2015, including: the area of arable land: 26.10 ha and permanent pasture 3.44 ha. The crop production in the farm is both oriented for commercial purposes and partly used for production of animal feed. The animal production in the analyzed years involved beef cattle and pork production in a closed cycle.

The crop production is dominated by the cultivation of plant which promote the degradation of soil organic matter: cereals, rape, maize, potatoes (Table 2), whose total ratio in the overall production was equal to $81.61 \%$ in the analyzed period.

Table 2. Crops obtained from production and their structure - mean results for period between 2012-2015.

\begin{tabular}{|l|c|c|c|}
\hline $\begin{array}{l}\text { Type of } \\
\text { crop }\end{array}$ & $\begin{array}{c}\text { Sown area } \\
{[\mathrm{ha}]}\end{array}$ & $\begin{array}{c}\text { Structure } \\
{[\%]}\end{array}$ & LSU ha $^{-1}$ \\
\hline $\begin{array}{l}\text { Total } \\
\text { cereals }\end{array}$ & 13.18 & 51.24 & \\
\hline Grain maize & 3.80 & 14.54 & \\
\cline { 1 - 2 } $\begin{array}{l}\text { Mixed } \\
\text { cereals and } \\
\text { grain } \\
\text { legumes }\end{array}$ & 4.44 & 16.98 & \multirow{2}{*}{0.51} \\
\hline Rape & 3.70 & 14.15 & \\
\hline Potatoes & 0.40 & 1.53 & \\
\hline $\begin{array}{l}\text { Grass in } \\
\text { arable land }\end{array}$ & 0.37 & 1.42 & \\
\cline { 1 - 3 } $\begin{array}{l}\text { Silage } \\
\text { maize }\end{array}$ & 0.04 & 0.14 & \\
\hline
\end{tabular}

Concurrently, the production of plants with a positive impact on the soil environment was low. These include mixed cereals and grain legumes and grass cultivated on arable land (18.39\%). This data suggests clearly that the crop rotation leads to excessive environment loading and the content of soil organic matter decreases as a consequence. Natural fertilizers (manure and slurry) are applied on the farm with the purpose of reducing the effect of soil degradation, which is accompanied by ploughing down straw and green mass grown as an aftercrop.

The stocking density per 1 ha of AL was equal to 0.51 expressed in livestock unit (LSU) in the analyzed period. In relation to the surface area of $\mathrm{AL}$, this parameter is low and does not guarantee the balance between the animal and plant production.

An increase of the stocking density could contribute to the use of the greater proportion of natural fertilizers in the place of chemical ones.

\subsection{Cumulative energy intensity of farming production}

The assessment of cumulative energy of farming production is applied as a tool to demonstrate how much energy is consumed by the processes and particular phases of a production process. The analysis involves a comprehensive insight into the energy intensity of the production. Table 3 contains the averaged results of production and cumulative energy intensity of the production in the analyzed farm between 2012-2015.

Table 3. Cumulative energy intensity and results of farming production - mean for 2012-2015.

\begin{tabular}{|c|c|c|}
\hline Specification & $\begin{array}{c}\text { Crop } \\
\text { production }\end{array}$ & $\begin{array}{c}\text { Animal } \\
\text { production }\end{array}$ \\
\hline $\begin{array}{l}\text { Cumulative energy } \\
\text { intensity of the } \\
\text { components of the } \\
\text { production process }[\mathrm{GJ}] \text { : }\end{array}$ & & \\
\hline Human labor & 37.61 & 41.35 \\
\hline Machines and equipment & 68.88 & 2.46 \\
\hline Fuel & 111.17 & 5.07 \\
\hline $\begin{array}{l}\text { Mineral fertilizers: NPK } \\
\text { and } \mathrm{CaO}\end{array}$ & 276.04 & \\
\hline $\begin{array}{l}\text { Sowing material and } \\
\text { planting stock }\end{array}$ & 74.71 & \\
\hline Protection agents & 23.6 & \\
\hline Purchased fodder & & 97.25 \\
\hline Electricity & & 7.92 \\
\hline $\begin{array}{l}\text { Cumulative energy } \\
\text { intensity - total }\end{array}$ & 627.38 & 154.05 \\
\hline $\begin{array}{l}\text { Cumulative energy } \\
\text { intensity per } 1 \text { ha - total }\end{array}$ & 21.24 & 5.21 \\
\hline \multicolumn{3}{|l|}{$\begin{array}{l}\text { Remaining indicators } \\
\text { and quantities: }\end{array}$} \\
\hline Generated GU - total & 1512.12 & 394.0 \\
\hline${\text { Generated GU } \cdot \mathrm{ha}^{-1}}^{-1}$ & 51.19 & 13.34 \\
\hline $\begin{array}{l}\text { Cumulative energy } \\
\text { intensity }\left[\mathrm{GJ} \cdot \mathrm{GU}^{-1}\right]\end{array}$ & 0.41 & 0.39 \\
\hline $\begin{array}{l}\text { Energy efficiency of } \\
\text { production }\left[\mathrm{GU} \cdot \mathrm{GJ}^{-1}\right]\end{array}$ & 2.41 & 2.56 \\
\hline
\end{tabular}

The farming production yielded on average $51.19 \mathrm{GU} \cdot \mathrm{ha}^{-1}$ from the plant production and 13.34 $\mathrm{GU} \cdot \mathrm{ha}^{-1}$ from the animal production. This means that plant production plays a principal role on the farm (in particular production of cereals, rape and maize), which provided nearly four times more production expressed in grain units. Besides, the cumulative energy intensity of plant production is also four times greater from animal production. The greater energy intensity of labor in the animal production results from the everyday clean-up activities in animal housings (manure handling). We can note a high ratio of the used fertilizers and protection agents (responsible for total of $48 \%$ ratio in the cumulative energy intensity of production). Besides, the use of fuel accounts for $15 \%$ of the overall cumulative energy intensity of production on the farm (Fig. 1), coupled with $12 \%$ of fodder. 


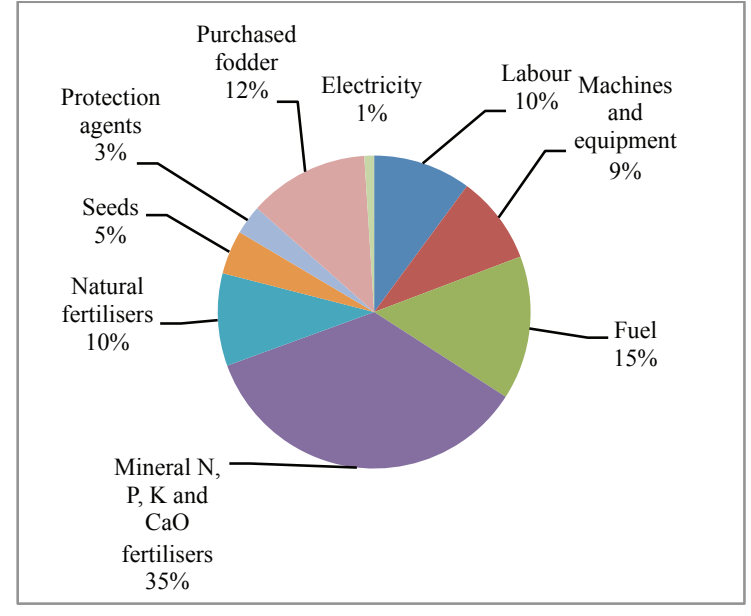

Fig. 1. Ratio of components of energy input of agricultural production.

However, similar results are demonstrated by other reports in this field [17-19].

Conventional system of production is followed in the analyzed farm and the use of chemical means of production significantly increases the energy intensity of the production in it.

Conventional system of production is followed in the analyzed farm and the use of chemical means of production significantly increases the energy intensity of the production in it. The results of various comparative studies performed with regard to selected types of conventional (intensive and extensive) farming as well as organic farming indicates the existence of considerable difference in the ratios of energy intensity of the components of the two systems. For the case of organic production, most commonly the cumulative energy intensity of the overall production is lower (Table 4). This is due to the avoidance of the considerable energy input contained in the chemical means of agricultural production.

Table 4. Examples of energy intensity of conventional and organic production systems.

\begin{tabular}{|c|c|}
\hline Production & Energy input $\left[\mathrm{MJ} \cdot \mathrm{ha}^{-1} \cdot \mathrm{y}^{-1}\right]$ \\
\hline Winter wheat (USA) ${ }^{4}$ & $1.77 \mathrm{E}+04$ \\
\hline Wheat (India) $^{3}$ & $1.18 \mathrm{E}+04$ \\
\hline $\begin{array}{l}\text { Corn -conventional } \\
(\text { USA) }\end{array}$ & $3.26 \mathrm{E}+04$ \\
\hline Corn - organic (USA) ${ }^{4}$ & $2.25 \mathrm{E}+04$ \\
\hline $\begin{array}{l}\text { Soyabean -organic } \\
\left(\text { USA) }{ }^{4}\right.\end{array}$ & $1.05 \mathrm{E}+04$ \\
\hline $\begin{array}{l}\text { Soyabean -conventional } \\
\left(\text { USA) }{ }^{4}\right.\end{array}$ & $1.26 \mathrm{E}+04$ \\
\hline $\begin{array}{l}\text { Winter wheat - } \\
\text { conventional (Poland) }{ }^{1}\end{array}$ & $2.39 \mathrm{E}+04$ \\
\hline $\begin{array}{l}\text { Winter wheat -organic } \\
\text { (Poland) }{ }^{1}\end{array}$ & $1.12 \mathrm{E}+04$ \\
\hline $\begin{array}{l}\text { Buckwheat - } \\
\text { conventional (Poland) }\end{array}$ & $7.97 \mathrm{E}+03$ \\
\hline $\begin{array}{l}\text { Buckwheat-organic } \\
\text { (Poland) })^{2}\end{array}$ & $1.12 \mathrm{E}+04$ \\
\hline
\end{tabular}

${ }^{1}[2],{ }^{2}[20],{ }^{3}[21],{ }^{4}[22]$

\subsection{Emergy analysis}

The diversity of production in the analyzed farm makes it difficult to obtain a detailed calculation regarding the use of emergy. This calculation needs to include a few simplifying assumptions. First, the mean duration of the plant stay in the fields was adopted to be equal to 168 days. On this basis, and using data from Table 1., we determined the emergy of the solar radiation and that of the wind. For the case of water, its use was determined on the basis of total precipitation in the area of the farm and the duration of plant vegetation.

The thermoecological cost of machines and equipment was derived to be equal to $11.76 \mathrm{E}+6 \mathrm{~J} \cdot \$^{-1}$ on the basis of [12]. The mean value of new machinery was taken to be equal to USD 30,000 and its depreciation period to be 12,000 hours. Hence, the calculation of the cumulative use of exergy gave $2.94 \mathrm{E}+7 \mathrm{~J} \cdot \mathrm{h}^{-1}$ related to the machine operation. The solar transformation was taken to be equal to $\tau=6.2 \mathrm{E}+7$, accounting for the earth sedimentation cycle. Due to the fact that the proportion of iron ores in steel production in Poland is equal to 0.4 , the value of $\tau$ was multiplied by this value. The resulting use of emergy associated with machine operation was calculated to be $E m=$ $7.29 \mathrm{E}+14 \mathrm{seJ} \cdot \mathrm{h}^{-1}$. The emergy of the fuel, mineral fertilizers and protection agents was derived by analogy to the data from the literature, as given in Table 1. The emergy of the purchased fodder and sowing material was taken to represent the emergy derived from renewable sources. Its specific value was adopted at the same level as for cereals. The emergy of electricity for the domestic conditions was regarded as non-renewable quantity. Table 5 below contains a summary of emergy representing the use of renewable and non-renewable sources during the production process, whereas Fig. 2 contains a summary of their per cent ratios.

The emergy calculations lead to the statement of the impact of the production on the environment. This purpose applied the following indicators [2325]: $P_{R}$ - to determine the ratio of emergy use from renewable sources (4), ELR (Environmental Loading Ratio) - to express the environmental load of the activities (5), EYR (Emergy Field Ratio) efficiency parameter (6) and use of emergy $(Y)$ per $\mathrm{GU}$ of the obtained production. The value of $Y(7)$ expresses the total use of emergy.

Below is a presentation of the formulae used to express the particular parameters:

$$
\begin{gathered}
P_{R}=\frac{E m_{R}}{Y} \\
E L R=\frac{E m_{M A T}+E m_{N M}+E m_{N S}+E m_{N F}}{E m_{R}} \\
E Y R=\frac{Y}{E m_{M A T}+E m_{N F}+E m_{N M}}
\end{gathered}
$$


Table 5. Use of particular components of production and the use of emergy respective to them $\left[\mathrm{seJ}^{\mathrm{J}} \cdot \mathrm{ha}^{-1} 1 \cdot \mathrm{y}^{-1}\right]$.

\begin{tabular}{|l|c|c|}
\hline \multicolumn{1}{|c|}{ Specification } & \multicolumn{2}{c|}{ Mean values: 2012-2015 } \\
\hline $\begin{array}{l}\text { Operating times of } \\
\text { machines and } \\
\text { equipment }\end{array}$ & $13.71[\mathrm{~h}]$ & $9.99 \mathrm{E}+15$ \\
\hline Fuel & $102.49[1]$ & $4.36 \mathrm{E}+14$ \\
\hline Fertilizers $(\mathrm{N})$ & $102.68[\mathrm{~kg}]$ & $4.15 \mathrm{E}+15$ \\
\hline Fertilizers $(\mathrm{P})$ & $13.52[\mathrm{~kg}]$ & $4.99 \mathrm{E}+14$ \\
\hline Fertilizers $(\mathrm{K})$ & $38.62[\mathrm{~kg}]$ & $7.22 \mathrm{E}+13$ \\
\hline Fertilizers $(\mathrm{CaO})$ & $841.31[\mathrm{~kg}]$ & $1.42 \mathrm{E}+15$ \\
\hline Fodder & $1007.11[\mathrm{~kg}]$ & $2.51 \mathrm{E}+15$ \\
\hline $\begin{array}{l}\text { Plant protection } \\
\text { agents }\end{array}$ & $2.88[\mathrm{~kg}]$ & $4.26 \mathrm{E}+13$ \\
\hline Electricity & $86.4 \mathrm{E}+6[\mathrm{~J}]$ & $1.38 \mathrm{E}+13$ \\
\hline Human labor & $26.73[\mathrm{~h}]$ & $1.14 \mathrm{E}+15$ \\
\hline $\begin{array}{l}\text { Time of solar } \\
\text { radiation }\end{array}$ & $168[\mathrm{day}]$ & $1.66 \mathrm{E}+12$ \\
\hline Time of using wind & $168[\mathrm{day}]$ & $4.69 \mathrm{E}+12$ \\
\hline $\begin{array}{l}\text { Mass of evaporated } \\
\text { water }\end{array}$ & $3.05 \mathrm{E}+5[\mathrm{~kg}]$ & $3.90 \mathrm{E}+14$ \\
\hline $\begin{array}{l}\text { Mass of decayed } \\
\text { organic matter }\end{array}$ & $503[\mathrm{~kg}]$ & $1.10 \mathrm{E}+15$ \\
\hline Seeds & $157.68[\mathrm{~kg}]$ & $1.02 \mathrm{E}+15$ \\
\hline \multicolumn{2}{|c|}{ Total $(\mathrm{Y})$} & $2.28 \mathrm{E}+16$ \\
\hline
\end{tabular}

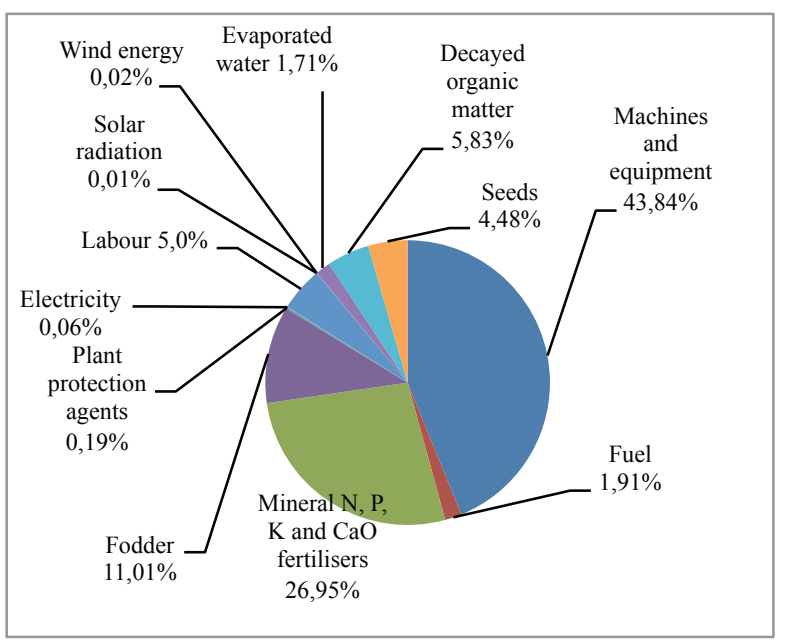

Fig. 2. Percent ratios of components of emergy in agricultural production on a farm.

$Y=E m_{R}+E m_{M A T}+E m_{N M}+E m_{N S}+E m_{N F}$

where:

$E m_{R}$ - total emergy derived from renewable sources: sun, wind, water, human labor, sowing material, fodder,

$Y$ - total use of emergy,

$E m_{M A T}$ - emergy of protection agents and fertilizers,

$E m_{N M}$ - emergy of machines and equipment,

$E m_{N S}$ - emergy of decayed organic matter,

$E m_{N F}$ - emergy of fuel and electricity.

The values of the estimated indicators $P_{R}, E L R$, $E Y R$ and $Y \cdot J Z^{-1}$ are presented in Table 6.
Table 6. Values of the emergy parameters of the production in the examined farm.

\begin{tabular}{|c|c|}
\hline Parameter & Value \\
\hline$P_{R}$ & 0.22 \\
\hline$E L R$ & 3.50 \\
\hline$E Y R$ & 1.37 \\
\hline$Y \cdot G U^{-1}$ & $1.20 \mathrm{E}+13$ \\
\hline
\end{tabular}

The emergy analysis demonstrates that the greatest degree of the emergy loading results from the operation of machines and equipment. This, in turn, is due to the considerable thermoecological cost (and high exergy demand) of the machines, equipment as well as high solar transformation for the case of the applied means of production. Machines and equipment apply a considerable load on the environment during each phase of their production and this load is accounted for in the emergy analysis at the stage of the application of these means in the agricultural production.

Similar as for the case of cumulative energy intensity, mineral fertilizers form a second important item in the account of the emergy use. We can note that in the examined example, emergies of the fuel and electricity are represented by relative low values. The ratio of emergy derived from renewable sources $\left(P_{R}\right)$ is responsible for $20 \%$ of the total emergy use and this value is considerable for the conditions in Poland. This is attributable to the relatively low value of the $E L R$ indicator (3.50), which describes the environmental load. We can bear in mind that each manner of cultivation characterized by a value of $E L R>1$ is considered to be responsible for environmental load [10]. The relatively low values of the $P_{R}$ and $E L R$ indicators in the analyzed farm result to a large degree from the substitution of natural fertilizers by mineral ones as well as the considerable ratio of fodder originating from renewable source in relation to the total emergy input. We can note at this point that the mean results of $E L R$ in the domestic production of cereals are in the range of 12 , although this value can be even a few times bigger.

\section{Conclusions}

The conducted study offers the statement of the following conclusions.

Mineral fertilizers represent the greatest proportion in the cumulative energy intensity. Other, comparable items on this list include: fuel, purchased fodder, human labor, natural fertilizers and machines and equipment. On average, the total energy intensity of plant production is equal to 21.24 $\mathrm{GJ} \cdot \mathrm{ha}^{-1}$ and this value corresponds to the standard energy intensity of the conventional production of cereals.

The energy intensity of both animal and plant 
production is equal to around $2.5 \mathrm{GU} \cdot \mathrm{GJ}^{-1}$. This is a typical value for conventional farms and a lower value in comparison to an example of organic winter wheat production (3.98 [2]).

The emergy analysis offers a more comprehensive insight of the impact of a given type of production on the environment. When it is applied for this purpose, solar transformation demonstrates the environmental value of the resources used in the generation of means of production. This type of analysis also accounts for the value of the renewable sources used in the agricultural production. From this analysis, it is clear that the highest ratio is represented by the use of emergy associated with machines and equipment (around 44\%). We can also note the considerable proportion associated with the use of mineral fertilizers (around 27\%). By comparison, the use of the emergy of the fuel is low, as it accounts for around $2 \%$.

The ELR indicator determined for the farm is low and equal to 3.50. This is affected by: limitation of the use of mineral fertilizers and their partial replacement by natural ones and the use of fodder which is regarded as originating from renewable sources. As a consequence, the ratio of renewable sources is equal to around $20 \%$.

\section{References}

1. http://www.enis-pv.com/naslonecznienie-wpolsce.html (access on-line 15.05.2017)

2. A. Kuczuk, J. Agri. Sci., 8, 4, 140-155 (2016)

3. H.T. Odum, Environmental accounting Emergy and Environmental Decision Making. (John Wiley\&Sons, Inc., 1996)

4. A. Kuczuk, S. Wacław, J. Res. Appl. Agri. Eng. 59, 4, 31-36 (2014)

5. K. Sławiński, J.Res. Appl. Agri. Eng. 55, 4, 99$101(2010)$

6. K. Sławiński, Inż. Rol. 4,129, 43-249 (2011)

7. Z. Wójcicki, Poszanowanie energii i środowiska w rolnictwie i na obszarach wiejskich, (IBMER, Warszawa,2 007)

8. S. Ulgiati, H.T. Odum., S. Bastianoni. Ecol. Model. 73, 215-268 (1994)

9. S.L. Brandt-Williams, Handbook of Emergy Evaluation. A Compendium Data for Emergy Computation Issued in Series of Folios (Centre for Environmental Policy, Environmental
Engineering Sciences, University of Florida, 2002)

10. J. Jankowiak, E. Miedziejko, J. Agri. Rur. Devel. 2, 12, 75-84 (2009)

11. J. Szargut, Termodynamika techniczna. (Wydawnictwo Politechnika Śląska Gliwice, 2000)

12. W. Stanek, Metodyka oceny skutków ekologicznych $w$ procesach cieplnych za pomoca analizy egzergetycznej (Wyd. Polit. Śl., Gliwice (2009)

13. E. Klugmann-Radziemska, Practical application of solar energy. Renewable Energy Sources in Opole Province. 1/POKL/8.2.1/2008:1-14 (2008)

14. Ochrona Środowiska, GUS, Warszawa (2014)

15. R. Burges, The use of emergy analysis for measuring the environmental costs and benefits of agriculture practices in Scotland (in): Emergy synthesis 6: Theory and Applications of the Emergy Methodology, CEP:265-271 (2011)

16. J. Kuś, Systemy gospodarowania $w$ rolnictwie. Rolnictwo integrowane. Materiały szkoleniowe, 49, IUNG, Puławy (1995)

17. J. Bojarszczuk, Stow. Ekon. Rol. i Agrob. Rocz. Nauk. XVI, 5, IUNG-PIB:15-21 (2014)

18. T. Dworakowski, Plonowanie $w$ różnych systemach produkcji - plonowanie roślin w różnych systemach produkcji, www.odr.pl (2011), (access on-line 15.05.2017)

19. S. Parafiniuk, Prob. Inż. Rol. 1, 79, 23-30 (2013)

20. A. Kuczuk, J. Res. Appl. in Agri. Eng. 61, 4 614 (2016)

21. D. Pimentel, H.M. Pimentel, Food, Energy and Society (Third Edition, Taylor and Francis Group, Boca Raton, London, New York, 2008)

22. D. Pimentel, Impacts of Organic Farming on the Efficiency of Energy Use in Agriculture - An Organic Center State of Science Review (2006)

23. D. Chen, Z. Luo, Ecol. Indic. 34, 623-626 (2013)

24. A.C. Haden, Emergy evaluations of Denmark and Danish agriculture - Assessing the Limits of Agricultural Systems to Power Society, Ekologisk Lantbruk 37, SLU (2003)

25. R.J. Singh, B.N. Ghosh, N.K. Shrama, S. Patra, K.S. Dadhwal, P.K. Mishra, Ecol. Indic. 61, 753-765 (2016) 